\title{
Factors Affecting Pregnant Women's have Nothihg in Prevention of Mother-to-Child Transmission Examination in Public Health Centers of Makassar in 2019
}

\author{
Bety Anisa Wulandari ${ }^{1}$, Arifin Seweng ${ }^{1 \star}$, M. Muhammad Arif Tiro $^{2}$, Anwar Mallongi $^{3}$, Muliati Muliati ${ }^{4}$ \\ ${ }^{1}$ Department of Biostatistic, Faculty of Public Health, Hasanuddin University, Makassar, Indonesia; ${ }^{2}$ Department of Statistics, \\ Faculty of Mathematics and Natural Sciences, Makassar, Indonesia; ${ }^{3}$ Department of Health Promotion and Behavioral Science, \\ Faculty of Public Health, Hasanuddin University, Makassar, Indonesia; ${ }^{4}$ Department of Environmental Health, Faculty of Public \\ Health, Hasanuddin University, Makassar, Indonesia
}

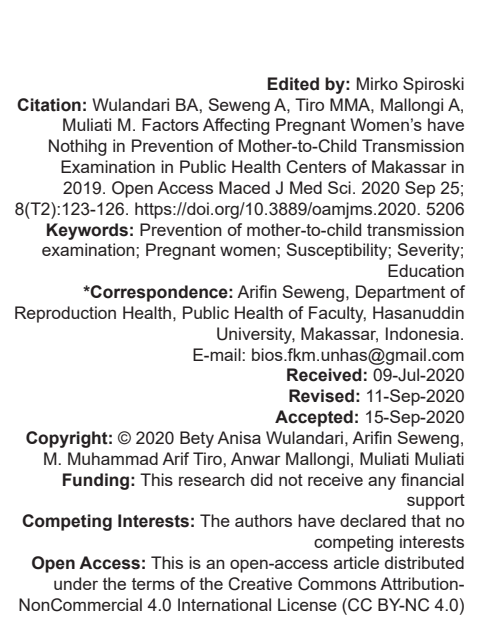

\section{Abstract}

BACKGROUND: Prevention of mother-to-child Human Immunodeficiency Virus (HIV) transmission or prevention of mother-to-child transmission (PMTCT) is part of efforts to control HIV-Acquired Deficiency Syndrome and sexually transmitted infections. In Indonesia, there were 1,805,993 pregnant women who were tested for HIV and there were 5074 (0.28\%) pregnant women who were HIV positive.

AIM: The purpose of this study was to analyze the factors that influence pregnant women not to conduct a PMTCT examination in Makassar City in 2019

METHODS: This study was an observational analytic study with cross-sectional design. The sample in this study was 260 pregnant women in the working area of the Sudiang Raya Health Center and Antang Perumnas Makassar City. Data were analyzed using Chi-square test and multiple logistic regressions.

RESULTS: The results showed that education affected pregnant women who did not conduct PMTCT examination with $p=0.013(p<0.05)$ with odds ratio $=4.571$ and there were some variables that were not significant such as age variable with $p=0.700(p>0.05)$, knowledge $p=0.621(p>0.05)$, perceived susceptibility $p=0.467(p>0.05)$, and perceived severity $p=1000(p>0.05)$

CONCLUSION: It was concluded that education affects pregnant women who do not conduct PMTCT examinations and for age, knowledge, perceived susceptibility and perceived severity do not affect pregnant women who do not conduct PMTCT examinations in Makassar City.

\section{Introduction}

Human Immunodeficiency Virus (HIV) is a disease caused by a virus that attacks white blood cells causing a decrease in the immune system, while Acquired Deficiency Syndrome (AIDS) is a collection of signs or symptoms that will arise due to a decrease in the immune system due to infection by a virus. HIV/ AIDS continues to be a major health problem for the global community and requires serious attention because every year the numbers increase [1].

Prevention of mother-to-child transmission (PMTCT) is part of efforts to control HIV-AIDS and sexually transmitted infections (STIs) in Indonesia and the Maternal and Child Health Program (MCH). PPIA services are integrated with $\mathrm{MCH}$, family planning (KB), reproductive health, and adolescent health service packages at every level of health services in the HIVAIDS and STI continuous comprehensive service strategy [2].
Globally, HIV incidence has decreased from 0.40/1000 uninfected populations in 2005-0.26 per 1000 uninfected populations in 2016. The African region remains the most affected by HIV, with an incidence rate of 1.24/1000 uninfected populations in 2016. In 2016, an estimated 1 million people died due to HIV-related illnesses, 120,000 of whom were children under the age of 15. The global increase in antiretroviral therapy (ART) has been a major driver of a $48 \%$ reduction in HIV-related deaths from a peak of 1.9 million in 2005. In mid-2017, around 20.9 million people received ART. However, ART only reached $53 \%$ of people living with HIV at the end of 2016, and rapid response acceleration is needed to increase the scope of care, along with other interventions throughout the service chain, including prevention, diagnosis, and chronic care [3].

According to data on the health profile of South Sulawesi province in 2018 out of 24 cities/regencies in South Sulawesi province, Makassar is the highest case of HIVIAIDS, with 772 HIV sufferers and 381 AIDS sufferers. Next is Bone with 77 HIV sufferers and 38 
AIDS sufferers and Palopo with $71 \mathrm{HIV}$ sufferers and 54 AIDS sufferers [4].

In recent years, various types of HIV control services in Indonesia have progressed and the number of people using them has also increased so that the goals of HIV control can be implemented. However, there are still several sub parts of the program that have not met the target. Because of the high number of HIVIAIDS cases and the lack of PMTCT coverage, the study aims to analyze the factors affecting pregnant women who did not conduct PMTCT examinations at Puskesmas Sudiang Raya and Antang Perumnas Makassar City in 2019.

\section{Materials and Methods}

This type of research is an observational analytic study with the research design used is crosssectional study. This research was conducted in the Sudiang Raya Health Center and Antang Perumnas Makassar City in September 2019.

The population in this study were all pregnant women who did ANC in January-July 2019 in the working area of the Sudiang Raya Health Center as many as 605 pregnant women and Puskesmas Antang Perumnas as many as 413 pregnant women. The samples in the study were 260 respondents divided by 155 respondents in the Sudiang Raya Community Health Center and 105 in the Antang Public Health Center.

Data collection was carried out by distributing questionnaires that were prepared in accordance with the objectives of the study given to respondents selected as research samples at the Sudiang Raya Health Center and the Antang Perumnas Health Center.

Data analysis techniques using univariate analysis, bivariate analysis with Chi-square test and multivariate analysis with multiple logistic regression in the SPSS For Windows Program.

\section{Results}

Table 1 shows the characteristics of respondents consisting of age and education. Most

Table 1: Distribution of mothers pregnant is not doing examination PMTCT based on the characteristics of capital

\begin{tabular}{lll}
\hline Characteristics & $\mathrm{N}$ & $\%$ \\
\hline Age of respondents & & \\
$\quad<20-35$ years & 222 & 85.3 \\
$\quad>35$ years & 38 & 14.7 \\
Education of respondents & 1 & \\
$\quad$ No school & 12 & 0.4 \\
$\quad$ Elementary school & 32 & 4.6 \\
Middle school & 130 & 12.3 \\
High school & 85 & 50.0 \\
$\quad$ Tertiary institution & & 32.7 \\
\hline PMTCT: Prevention of mother-to-child transmission.
\end{tabular}

respondents in the age group $<20-35$ years old were $222(85.3 \%)$, while 38 respondents $(14.7 \%)$ were in the age group $>35$ years. For education variables, the most respondents were high school education as many as 130 respondents $(50.0 \%)$, while the fewest respondents who were not in school were 1 respondent $(0.4 \%)$.

Table 2 shows the distribution of respondents based on research variables. Distribution of respondents

Table 2: Distribution of mothers pregnant is not doing examination PMTCT

\begin{tabular}{lll}
\hline Perception & $\mathrm{n}$ & $\%$ \\
\hline PMTCT examination & 13 & \\
$\quad$ No PMTCT & 247 & 5.0 \\
PMTCT & & 95.0 \\
Age & 223 & 85.8 \\
$\quad$ Young & 37 & 14.2 \\
$\quad$ Old & 45 & 17.3 \\
Education & 215 & 82.7 \\
$\quad$ Low & & \\
$\quad$ High & 25 & 9.6 \\
Knowledge & 235 & 90.4 \\
$\quad$ Less & 12 & 4,6 \\
$\quad$ Enough & 248 & 95.4 \\
Perceived Susceptibility & & \\
$\quad$ Less & 20 & 7.7 \\
$\quad$ Enough & 240 & 92.3 \\
Perceived Severity & & \\
$\quad$ Less & & \\
$\quad$ Enough & &
\end{tabular}

based on PMTCT status, most respondents who were PMTCT were 247 (95.0\%) while respondents who were not PMTCT were 13 (5.0\%). Distribution of respondents based on age mostly at young age as many as 223 respondents (85.5\%), while respondents at old age were 37 respondents (14.2\%). Distribution of respondents based on education mostly in higher education as many as 215 respondents $(82.7 \%)$, while respondents who had low education were 45 respondents (17.3\%). Distribution of respondents based on knowledge most of the knowledgeable enough is 235 respondents (90.4\%), while respondents who lack knowledge are 25 respondents (9.6\%). Distribution of respondents based on the perceived susceptibility most of the respondents with enough perceived susceptibility is 248 respondents $(95.4 \%)$, while respondents with less perceived susceptibility are 12 respondents (4.6\%). Distribution of respondents based on the perceived severity most of the respondents with enough perceived severity is 240 respondents $(92.3 \%)$, while respondents with a perceived severity are less as many as 20 respondents $(7.7 \%)$.

Table 3 shows the distribution of respondents based on research variables on the PMTCT examination. Respondents who experienced PMTCT were more likely to occur at a young age, as many as 12 respondents $(5.4 \%)$ compared to respondents who were older, namely, 1 respondent $(2.7 \%)$ with a $p>0.05$. Respondents who experienced PMTCT were more likely to be respondents with tertiary education as many as seven respondents $(3.3 \%)$ compared to low education respondents, that is, as many as six respondents $(13.3 \%)$ with $p<0.05$. Respondents who experienced PMTCT were more likely to have sufficient knowledge, namely, as many as 13 respondents (5.5\%) compared 
Table 3: Factors affecting pregnant women not doing the PMTCT examination

\begin{tabular}{|c|c|c|c|c|c|c|c|}
\hline \multirow[t]{3}{*}{ Variable } & \multicolumn{6}{|c|}{ PMTCT } & \multirow[t]{3}{*}{$p$-value } \\
\hline & \multicolumn{2}{|c|}{ No PMTCT } & \multicolumn{2}{|c|}{ PMTCT } & \multicolumn{2}{|c|}{ Amount } & \\
\hline & $\mathrm{n}$ & $\%$ & $\mathrm{n}$ & $\%$ & $\mathrm{n}$ & $\%$ & \\
\hline \multicolumn{8}{|l|}{ Age } \\
\hline Young & 12 & 5.4 & 211 & 94.6 & 223 & 100.0 & 0.700 \\
\hline Old & 1 & 2.7 & 36 & 97.3 & 37 & 100.0 & \\
\hline \multicolumn{8}{|l|}{ Education } \\
\hline Low & 6 & 13.3 & 39 & 86.7 & 45 & 100.0 & 0.013 \\
\hline High & 7 & 4.7 & 208 & 96.7 & 215 & 100.0 & \\
\hline \multicolumn{8}{|l|}{ Knowledge } \\
\hline Less & 0 & 0.0 & 25 & 100 & 25 & 100.0 & 0.621 \\
\hline Enough & 13 & 5.5 & 222 & 94.5 & 235 & 100.0 & \\
\hline \multicolumn{8}{|c|}{ Perceived susceptibility } \\
\hline Less & 1 & 8.3 & 11 & 91.7 & 12 & 100.0 & 0.467 \\
\hline Fair & 12 & 4.8 & 236 & 95.2 & 248 & 100.0 & \\
\hline \multicolumn{8}{|c|}{ Perceived severity } \\
\hline Less & 4 & 19.0 & 17 & 81.0 & 21 & 100.0 & 0.014 \\
\hline Enough & 9 & 3.8 & 230 & 96.2 & 239 & 100.0 & \\
\hline
\end{tabular}

to respondents who lacked knowledge with a value of $p>0.05$. Respondents who did not PMTCT were more likely to have experienced perceived susceptibility, namely, as many as 12 respondents $(4.8 \%)$ compared to respondents who were less susceptible perceptions, namely, as many as 1 respondent ( $8.3 \%$ ) with a $p>0.05$. Respondents who did not have PMTCT were more likely to have sufficient perceived severity, as many as 12 respondents $(5.0 \%)$ compared to respondents with less perceived severity, namely, as many as 1 respondent $(5.0 \%)$ with a $p>0.05$.

Table 4 shows the conclusions of multivariate analysis with multiple logistic regressions of the five independent variables entered into the test simultaneously only education has a consistent significance. Hence, it can be concluded that education with an odds ratio value of $4.571>1$ is a risk factor with a lower-upper value $=1458-14,334$, which means pregnant women with low education are 4 times more likely to not have PMTCT examinations compared to pregnant women with higher education.

Table 4: Results of test multivariate factors that affect mothers pregnant do checks PMTCT in Makassar city year 2019

\begin{tabular}{llcccccc}
\hline Variable & B & Wald & Df & p-value & OR & \multicolumn{2}{c}{$95 \%$ Cl for Exp (B) } \\
\cline { 3 - 8 } & & & & & Lower & Upper \\
\hline Education & 1.520 & 0.583 & 1 & 0.009 & 4.571 & 1.458 & 14.334 \\
\hline
\end{tabular}

PMTCT: Prevention of mother-to-child transmission, OR: odds ratio.

\section{Discussion}

This study shows that there are several factors that do not affect pregnant women undergoing PMTCT examinations. Where there are several factors including education, age, knowledge, perception of vulnerability, and perception of severity.

This research shows that education influences pregnant women who do not conduct PMTCT examinations in Makassar City. Education is the last formal education ever completed by respondents. The high level of education causes pregnant women to be compliant with examinations in pregnancy, including screening for HIVIAIDS. Likewise, highly educated mothers will check their pregnancy in an orderly manner while maintaining the health condition of herself and the fetus it contains. The education of respondents in this study is good but higher education does not necessarily describe the acceptance of pregnant women toward PMTCT examinations.

This study is not in line with the research of Halim [5], the results of bivariate analysis showed that a statistical test with a significance level of $5 \%$ was obtained $p=0.550$, which means that statistically there was no relationship between education and HIV examination behavior. Research Setiyawati and Meilani [6] is not in line with this study that there is no relationship between the levels of education with HIV test behavior in pregnant women. This study is in line with the study of Umar and Erni [7] which concluded that there was a significant relationship between education and the acceptance of HIV testing by pregnant women.

This study also showed that age, knowledge, perceived susceptibility, and perceived severity did not affect pregnant women who did not conduct PMTCT examinations in Makassar City. For the age variable, age is the length of life that passed from the time of birth until the time of the study. The age of respondents in this study is 17 years and the lowest is 45 years. HIV testing behavior more at a young age than old age because of the perception of HIV risk is low when you get older. This research is in line with Halim et al. [5] which states that there is no relationship between age and the behavior of pregnant women in HIV testing

For the knowledge variable, the knowledge referred to in this study includes knowledge about behavior that has the potential to transmit HIVIAIDS, body fluids that can transmit HIVIAIDS, ways to find out someone infected with HIVIAIDS, HIV counseling and testing, PMTCT services, how to prevent HIV transmission from a pregnant woman to her fetus. For the respondents' knowledge, most of them are knowledgeable, but sufficient knowledge cannot be used as a benchmark for someone taking an HIV test themselves. This study is not in line with research conducted by Arniti et al. [8] which shows that there is a relationship between knowledge of pregnant women and the acceptance of HIV testing. This study is in line with Fatimah and Hati [9] which concluded that there is no relationship between the levels of knowledge of pregnant women about HIVIAIDS with PITC examination behavior in pregnant women at the Sleman Yogyakarta Public Health Center.

For the susceptibility variable, perceived susceptibility is not a factor that influences a person to conduct PMTCT examination. This is because respondents already know that HIVIAIDS is an incurable disease so that respondents feel the need to conduct PMTCT examinations. This study is in line with the study of Wenny et al. [10], there is no relationship between 
susceptibility perceptions with HIV testing in pregnant women. Legiati et al. [11], there is a relationship between perceived susceptibility with test behavior.

For the severity variable, a person who has sufficient perceived severity about an illness is not always in line with the behavior in his life [11], [12], [13], [14]. This can be influenced by environmental factors that are driving so that someone is motivated to adopt healthy behaviors. This study is in line with Wenny et al. [10] perceived severity not significantly related to HIV test behavior in pregnant women. This study is not in line with the research of Arniti et al. [8] obtained a significant relationship between the perceived severity with the acceptance of HIV testing by pregnant women.

\section{Recommendation}

It is expected that an increase in information and education communication (IEC) communication services for health workers regarding HIV and PMTCT information so that pregnant women have additional knowledge about HIV and PMTCT especially pregnant women with education who are not in school and have completed primary school.

\section{References}

1. Nurjanah NA, Wahyono TY. Tantangan pelaksanaan program prevention of mother to child transmission (PMTCT): Systematic review. J Kesehatan Vokasional. 2019;4(1):55-64. https://doi. org/10.22146/jkesvo.41998

2. Nurtikasari A, Soraya R. Perbedaan pengetahuan ibu hamil tentang pencegahan penularan human immunodeficiency virus (HIV) dari ibu ke anak (PPIA) sebelum dan sesudah diberi penyuluhan (desa gampeng kecamatan gampengrejo kabupaten kediri). J Kebidanan. 2017;6(2):94-9. https://doi. org/10.35890/jkdh.v6i2.37
3. World Health Organization. Monitoring Health For The Sustainable Development Goals. Geneva: World Health Organization; 2018.

4. Dinas Kesehatan Sulawesi Selatan. Profil Dinas Kesehatan Sulawesi Selatan. Sulawesi Selatan, Makassar: Dinas Kesehatan Sulawesi Selatan; 2018. https://doi.org/10.32382/ medkes.v13i2.691

5. Halim $Y$, Syamsul HB, Kusumawati A. Faktor-faktor yang berhubungan dengan perilaku ibu hamil dalam pemeriksaan HIV di wilayah kerja Puskesmas Halmahera Kota Semarang. J Kesehatan Masyarakat. 2016;4(5):395-405. https://doi. org/10.14710/jpki.12.1.115-133

6. Setiyawati N, Meilani N. Determinan perilaku tes HIV pada ibu hamil. Kesmas Natl Public Health J. 2015;9(3):201-6. https:// doi.org/10.21109/kesmas.v9i3.565

7. Umar F, Erni E. Faktor yang berhubungan dengan penerimaan tes HIV oleh ibu hamil. J Kesehatan Masyarakat. 2019;9(1):13742. https://doi.org/10.15562/phpma.v2i1.125

8. Arniti NK, Wulandari LP, Wirawan DN. Faktor-faktor yang berhubungan dengan penerimaan tes HIV oleh ibu hamil di Puskesmas Kota Denpasar. Public Health Prev Med Arch. 2014;2(1):81-2. https://doi.org/10.15562/phpma.v2i1.125

9. Fatimah F, Hati FS. Tingkat pengetahuan ibu hamil tentang HIV/ AIDS dengan perilaku pemeriksaan test PITC (provider initiated test and counselling) di Puskesmas Sleman Yogyakarta. J Ners dan Kebidanan Indones. 2015;3(1):48-52. https://doi. org/10.21927/jnki.2015.3(1).48-52

10. Wenny DM, Subronto YW, Hakimi M. Faktor yang memengaruhi partisipasi ibu hamil melakukan skrining HIV di puskesmas Yogyakarta. Berita Kedokteran Masyarakat. 2016;32(11):43542. https://doi.org/10.22146/bkm.11326

11. Syam A, Sari NP, Thaha AR, Suriah S, Jafar N, Salam A, et al The effect of pumpkin seed flour (Cucurbita moschata Durch) on zinc serum levels in malnourished Wistar rats. Enferm Clin. 2020;30(4):337-40. https://doi.org/10.1016/j.enfcli.2019.10.095 PMid:32545081

12. Muhith A, Winarti E, Perdana SS, Haryuni S, Rahayu KI, Mallongi A. Internal locus of control as a driving factor of early detaction behavior of servical cancer by inspection visual of acetic acid method. Open Access Maced J Med Sci. 2020;8(E):113-6. https://doi.org/10.3889/oamjms.2020.4341

13. Mallongi A, Birawida AB, Astuti RD, Saleh M. Effect of lead and cadmium to blood pressure on communities along coastal areas of Makassar, Indonesia. Enferm Clín. 2020;30(4):313-7. https:// doi.org/10.1016/j.enfcli.2020.03.001

14. Legiati T, Shaluhiyah Z, Suryoputro A. Perilaku ibu hami untuk tes HIV di kelurahan bandarharjo dan Tanjung Mas kota Semarang. J Promosi Kesehatan Indones. 2012;7(1):74-85. https://doi.org/10.14710/jpki.12.1.115-133 